(0.67) vs those who did not (0.36) and AB/FF 400/12 $\mu \mathrm{g}$ significantly reduced the rate of exacerbations vs PBO $(\mathrm{p}<0.05$; Table 1). The overall AE frequency was similar throughout (range with ICS, 54.8-60.7\%; without, 56.0-60.3\%). The most common AEs across patient groups were COPD exacerbation, nasopharyngitis and headache, irrespective of ICS use.

Conclusion In this analysis, aclidinium/formoterol 400/12 $\mu \mathrm{g}$ twice daily improved bronchodilation and dyspnoea in patients independent of ICS use and reduced exacerbations in patients using ICS. Combining $\mathrm{AB}$ and FF along with an ICS increased bronchodilation vs either monotherapy. $\mathrm{AE}$ frequencies were similar between the patient groups, regardless of ICS use.

Abstract S60 Table 1 Change from baseline in morning pre-dose (trough) $\mathrm{FEV}_{1}$ at Week 24 and rate of exacerbations by concomitant ICS use

\begin{tabular}{lllll} 
AB/FF & AB/FF & AB & FF & Placebo \\
$400 / 12 \mu g$ & $400 / 6 \mu g$ & $400 \mu g$ & $12 \mu g$ & BID \\
BID & BID & BID & BID & \\
\hline
\end{tabular}

LS mean change from baseline in morning pre-dose (trough) FEV $_{1}$ at Week 24 by ICS use, $\mathrm{mL}^{\mathrm{a}}$

\begin{tabular}{lccccc} 
ICS use & $98^{* * *}$ & $47^{* * *}$ & $44^{* * *}$ & $27^{* *}$ & -47 \\
No ICS use & $85^{* * *}$ & $71^{* * *}$ & $71^{* * *}$ & $18^{* * *}$ & -50 \\
\multicolumn{7}{l}{$\begin{array}{l}\text { Rate of exacerbations } \\
\text { ICS use }\end{array}$} & $0.40^{*}$ & 0.53 & 0.59 & 0.45 & 0.67 \\
No ICS use & 0.31 & 0.27 & 0.29 & 0.44 & 0.36
\end{tabular}

${ }^{a}$ Analyses based on the mixed model for repeated measures: treatment effects and treatment comparisons.

${ }^{\mathrm{b}}$ Analysis based on the log-linear model.

${ }^{*} \mathrm{p}<0.05$ vs placebo: ${ }^{* *} \mathrm{p}<0.01$ vs placebo: ${ }^{* * *} \mathrm{p}<0.0001$ vs placebo.

$A B$, aclidinium bromide; BID, twice daily; $F \mathrm{EV}_{1}$, forced expiratory volume in $1 \mathrm{~s}$; FF, formo-

terol fumarate; ICS, inhaled corticosteroid; LS, least squares.

\section{S61 ANALYSIS OF THE EFFICACY AND SAFETY OF THE COMBINATION OF TIOTROPIUM + OLODATEROL IN PATIENTS WITH COPD BY PREVIOUS USAGE OF INHALED CORTICOSTEROIDS}

${ }^{1} \mathrm{~S}$ Korn, ${ }^{1} \mathrm{R}$ Buhl, ${ }^{2} \mathrm{~L}$ Grönke, ${ }^{2} \mathrm{~L}$ Korducki, ${ }^{2} \mathrm{VC}$ Amato, ${ }^{3} \mathrm{GT}$ Ferguson, ${ }^{4} \mathrm{R}$ Abrahams. ${ }^{1}$ Pulmonary Department, Mainz University Hospital, Mainz, Germany, ${ }^{2}$ Boehringer Ingelheim Pharma GmbH and Co. KG, Ingelheim, Germany; ${ }^{3}$ Pulmonary Research Institute of Southeast Michigan, Livonia, Michigan, USA; ${ }^{4}$ Morgantown Pulmonary Associates, Morgantown, West Virginia, USA

\subsection{6/thoraxjnl-2015-207770.67}

Rationale Tiotropium (T), a long-acting muscarinic antagonist, and olodaterol $(\mathrm{O})$, a long-acting $\beta_{2}$-agonist (both administered once daily), have been studied as a once-daily combination. Two Phase III studies have demonstrated that $\mathrm{T}+\mathrm{O}$ significantly improved lung function and symptoms over $\mathrm{T}$ and $\mathrm{O}$ monotherapy treatments in patients with moderate to very severe chronic obstructive pulmonary disease (COPD). ${ }^{1}$ During these studies, patients were allowed to continue existing treatment with inhaled corticosteroids (ICS); this analysis was conducted to determine the effects of study treatment in patients receiving or not receiving ICS as reported at baseline.

Methods A total of 5162 patients were randomised to treatment with $\mathrm{O} 5 \mu \mathrm{g}, \mathrm{T} 2.5 \mu \mathrm{g}$, T $5 \mu \mathrm{g}, \mathrm{T}+\mathrm{O} 2.5 / 5 \mu \mathrm{g}$ or $\mathrm{T}+\mathrm{O} 5 / 5 \mu \mathrm{g}$ (Respimat ${ }^{\circledR}$ inhaler) in two 52-week, double-blind, parallel-group studies (NCT01431274 and NCT01431287). Primary efficacy end points were trough forced expiratory volume in $1 \mathrm{~s}\left(\mathrm{FEV}_{1}\right)$ response (ie, change from baseline), $\mathrm{FEV}_{1}$ area under the curve from $0-3 \mathrm{~h}\left(\mathrm{AUC}_{0-3}\right)$ response and St George's Respiratory
Questionnaire (SGRQ) total score after 24 weeks. Pooled data are presented for the patient subgroups either using or not using ICS at baseline.

Results In the overall population, all treatments resulted in clinically relevant improvements in lung function, with significant increases with both $\mathrm{T}+\mathrm{O}$ doses over the individual components $(\mathrm{p}<0.01) .^{1}$ These effects on lung function were observed irrespective of whether or not patients had reported concomitant use of ICS at baseline (see Table 1). In the 'ICS usage' and 'no ICS usage' subgroups, there were no statistically significant differences between the combinations and monotherapy treatments in changes in SGRQ total scores from baseline to Week 24, although SGRQ total scores were improved during this period with $\mathrm{T}+\mathrm{O}$.

\begin{tabular}{|c|c|c|c|c|}
\hline & \multicolumn{2}{|c|}{ Trough FEV ${ }_{1}, \mathrm{~L}$} & \multicolumn{2}{|c|}{$\mathrm{FEV}_{1} \mathrm{AUC}_{0-3}, \mathrm{~L}$} \\
\hline & n & Adjusted mean (SE) change & $\mathbf{n}$ & Adjusted mean (SE) change \\
\hline \multicolumn{5}{|c|}{ ICS usage } \\
\hline 05 & 497 & $0.046(0.009)$ & 503 & $0.129(0.009)$ \\
\hline Т 2.5 & 471 & $0.084(0.009)$ & 476 & $0.142(0.009)$ \\
\hline T 5 & 464 & $0.088(0.009)$ & 465 & $0.147(0.009)$ \\
\hline $\mathrm{T}+0$ & 489 & 0.114 & 492 & 0.246 \\
\hline $2.5 / 5$ & & $(0.009)^{\dagger \#^{*}}$ & & $(0.009)^{\dagger ; \# \#^{* \star}}$ \\
\hline$T+05 / 5$ & 503 & $0.133(0.009)^{\dagger ; \# \#^{* \star}}$ & 505 & $0.260(0.008)^{\dagger \# \# \#^{* *}}$ \\
\hline \multicolumn{5}{|c|}{ No ICS usage } \\
\hline 05 & 510 & $0.067(0.009)$ & 514 & $0.139(0.009)$ \\
\hline Т 2.5 & 533 & $0.062(0.009)$ & 537 & $0.132(0.008)$ \\
\hline T 5 & 536 & $0.073(0.009)$ & 543 & $0.155(0.008)$ \\
\hline $\mathrm{T}+0$ & 511 & 0.122 & 517 & 0.252 \\
\hline $2.5 / 5$ & & $(0.009)^{\dagger \# \# * *}$ & & $(0.008)^{\dagger \# \# \#^{* \star}}$ \\
\hline$T+05 / 5$ & 500 & $0.149(0.009)^{\dagger \# \# \#^{\star \star}}$ & 503 & $0.263(0.009)^{\dagger \# \# \#^{* *}}$ \\
\hline
\end{tabular}

${ }^{\dagger} \mathrm{p}<0.0001$ vs $05 ;{ }^{\# \#} \mathrm{p}<0.0001$ vs T $2.5 ;{ }^{* *} \mathrm{p}<0.001$ vs T 5 .

a Patients were not recorded as receiving LAMA or LABA at baseline in this study. $\mathrm{SE}$, standard error.

Conclusions In patients with COPD, $\mathrm{T}+\mathrm{O} 5 / 5 \mu \mathrm{g}$ significantly improved lung function over $\mathrm{T} 5 \mu \mathrm{g}$ and $\mathrm{O} 5 \mu \mathrm{g}$ monotherapy, irrespective of whether patients had reported ICS use at baseline.

Funding Boehringer Ingelheim.

\section{REFERENCE}

1 Buhl R, et al. Eur Respir J. 2015;45:969-979

\section{Mechanisms of lung injury and fibrosis remodelling on the fly}

\section{S62 USING DROSOPHILA MELANOGASTER TO STUDY PATHOGENIC MUTANTS OF SURFACTANT PROTEIN C}

E Malzer, SJ Marciniak. University of Cambridge, Cambridge, UK

10.1136/thoraxjnl-2015-207770.68

Introduction and objectives Surfactant protein C (SFTPC) is secreted by type II pneumocytes to reduce alveolar lining fluid surface tension and thus prevent alveolar collapse at low lung volumes. The immature form of SFTPC must undergo proteolytic 